\title{
Analiza i waloryzacja krajobrazu gminy wiejskiej Ostróda
}

\section{Analysis and valuation of the landscape of the rural commune of Ostróda}

\author{
Mariusz ANTOLAK \\ Uniwersytet Warmińsko-Mazurski w Olsztynie \\ Katedra Architektury Krajobrazu \\ ul. Prawocheńskiego 17, 10-720 Olsztyn \\ mariusz.antolak@uwm.edu.pl
}

Zarys treści: W artykule zaprezentowano autorski warsztat metodyczny analizy i waloryzacji krajobrazu gminy wiejskiej stworzony na potrzeby planowania przestrzennego. Badaniami objęto obszar gminy Ostróda o powierzchni $401 \mathrm{~km}^{2}$. W ramach analizy dokonano podziału terenu na jednostki krajobrazowe (typy i podtypy krajobrazu). Na terenie opracowania przeanalizowano powiązania kompozycyjne, wnętrza krajobrazowe, elementy wyróżniające się oraz ekspozycję. Do szczegółowej analizy krajobrazu wybrano 20 miejscowości. Dla każdej z nich opracowano dwie karty krajobrazu oraz wykonano uproszczoną waloryzację w postaci tabelarycznej.

Słowa kluczowe: planowanie przestrzenne, architektura krajobrazu, waloryzacja, krajobraz, Mazury.

\section{Wprowadzenie}

Teoretyczne podstawy sporządzania analiz i waloryzacji krajobrazu najszerzej sformułowane zostały przez pracowników związanych z obecnym Wydziałem Architektury Politechniki Krakowskiej: Z. Nováka, G. Ciołka, J. Bogdanowskiego (Bogdanowski 1976; Bogdanowski i in. 1981; Ciołek 1964) i kontynuowane są współcześnie przez kolejne pokolenia tej szkoły. Tu zrodziły się definicje i typologie krajobrazu, teoria wnętrza krajobrazowego oraz metody studiów i analiz krajobrazowych. Temat wnętrza urbanistycznego szerzej został rozwinięty w pracach A. Böhma $(1981,1998)$ oraz P. Patoczki (2000). Powiązania architektury z planowaniem przestrzennym prezentowali m.in. A. Böhm (2006) oraz K. Pawłowska (2001).

Zdecydowanie odmienne metody dotyczące analiz krajobrazu wywodzą się ze środowiska olsztyńskiego. Metoda WNET (wykorzystująca naturalne elementy terenu), opracowana przez R. Cymermana i J. Koca, uzależnia atrakcyjność krajobrazu od występowania w przestrzeni jak największej liczby elementów naturalnych. Przy jej pomocy możliwe jest wyznaczenie obszarów o zróżnicowanych warunkach ekologicznych oraz krajobrazowych. Cechami diagnostycznymi mogą być tutaj: szata roślinna, wody, stopień wykorzystania 
terenu, rzeźba terenu, ochrona krajobrazu i gleba. Metoda macierzy wartości (optymalnego sposobu użytkowania) T. Bajerowskiego (1991) zakłada wykorzystanie informacji zawartych w ogólnie dostępnych materiałach kartograficznych (map ewidencyjnych i topograficznych). Macierz inwentaryzacyjna przybiera postać macierzy zerojedynkowej (Bajerowski 1996). Jedynka oznacza występowanie danej cechy, a zero jej brak. W wyniku analizy po przydzieleniu określonym polom podstawowym poszczególnych wartości można uzyskać informację o potrzebie zmiany funkcji planistycznej danej przestrzeni. Metoda ogranicza się wyłącznie do prac kameralnych, pomijając wiele istotnych czynników pozamaterialnych.

Celem niniejszej pracy jest analiza krajobrazów gminy wiejskiej Ostróda oraz analiza i waloryzacja krajobrazów wybranych miejscowości występujących na jej terenie. Do badań wykorzystano metodę przydatną w praktyce planowania przestrzennego na poziomie gminy (Antolak 2013). Badaniami objęto obszar o powierzchni 401 km².

\section{Typy i podtypy krajobrazów}

Pierwszym etapem badania był podział terenu na typy i podtypy krajobrazu. Wyznaczono je, biorąc pod uwagę ukształtowanie terenu oraz jego aktualne pokrycie (ryc. 1). Uwzględniono następujące elementy: wody powierzchniowe, lasy, tereny wykorzystywane rolniczo i sieć osadniczą. Wydzielono 4 typy krajobrazów:

Typ 1 - krajobraz rolniczy ze zwartymi układami ruralistycznymi oraz licznymi linearnymi układami roślinnymi, z dużą liczbą niewielkich zbiorników wodnych, w którym wydzielono dwa podtypy:

$1 \mathrm{~A}$ - teren lekko falisty,

1B - teren wyraźnie pofałdowany.

Typ 2 - obszary leśne z pojedynczymi polanami śródleśnymi oraz z leśnymi zbiornikami wodnymi. W typie wydzielono cztery podtypy:

2A - teren z dominującym udziałem lasów iglastych, lekko falisty z większymi rynnami polodowcowymi, z dużymi jeziorami rynnowymi,

2B - teren z dominującym udziałem lasów iglastych, płaski, z niewielkimi wyniesieniami, wzdłuż doliny Drwęcy, pozbawiony większych zbiorników wodnych,

2C - obszar z dominującym udziałem lasów liściastych, z silnie urozmaiconą rzeźbą terenu, rynny polodowcowe częściowo wypełnione zbiornikami wodnymi,

2D - obszar z dominującym udziałem lasów liściastych (duży udział buka), wyraźnie wyniesiony i urozmaicony, z nielicznymi śródleśnymi zbiornikami wodnymi.

Typ 3 - doliny głównych cieków wodnych. W typie wydzielono dwa podtypy:

3A - szeroka dolina Drwęcy w zachodniej części gminy, z niewielkim udziałem zadrzewień śródpolnych,

3B - wąskie i miejscowo stromo zakończone doliny Drwęcy i Grabiczka we wschodniej części gminy, z pojedynczymi jeziorami przepływowymi oraz miejscowo z dużym udziałem zadrzewień.

Typ 4 - podmiejska strefa rozwojowa z dwoma podtypami:

$4 \mathrm{~A}$ - strefa śródleśna,

4B - strefa śródpolna. 


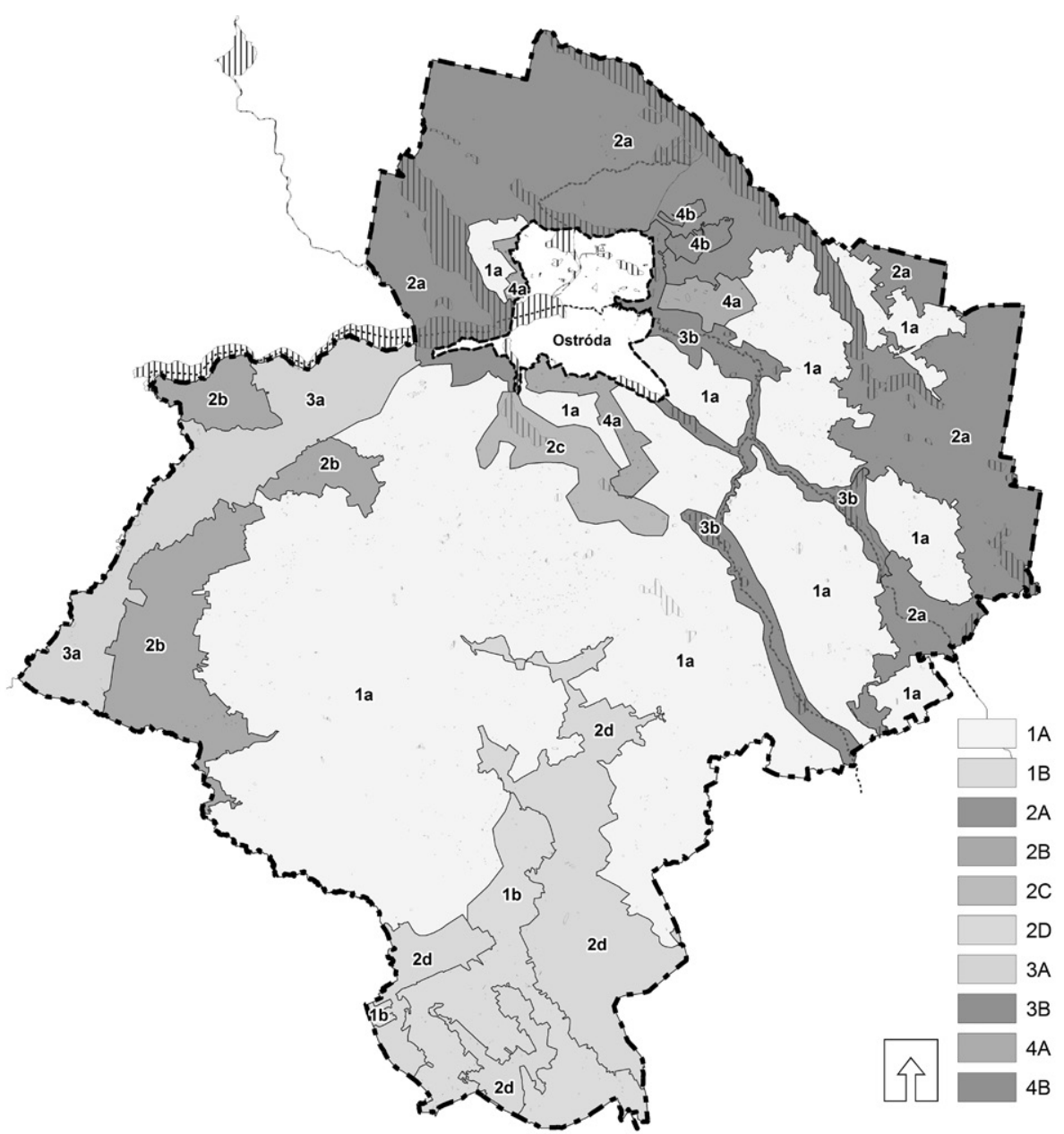

I granica gminy wiejskiej Ostróda (borders of the rural commune of Ostróda)

$|\mathrm{I}||||| \mid$ zbiorniki wodne (water reservoirs)

granica gminy miejskiej Ostróda (borders of the urban municipality of Ostróda) typy i podtypy krajobrazu (types and subtypes of landscape)

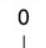

3

Ryc. 1. Typy i podtypy krajobrazu gminy wiejskiej Ostróda Types and subtypes of landscape in the rural commune of Ostróda Źródło: opracowanie własne / Source: own study

\section{Analiza krajobrazu}

Dla obszaru opracowania sporządzono uproszczoną analizę krajobrazową bazującą na czterech podstawowych składowych: powiązaniach kompozycyjnych, wnętrzach krajobrazowych, elementach wyróżniających się i ekspozycji.

Podstawowe osie kompozycyjne (widokowe) na badanym terenie stanowią ciągi komunikacyjne. Podkreśleniem osi są w wielu przypadkach nasadzenia szpalerowe lub alejowe (również przy drogach w sąsiedztwie terenu opracowania). Wpływają one na jakość od- 
bioru drogi, jako ciągu kompozycyjnego. Osiami wyraźnie zarysowanymi na analizowanym terenie są ponadto ciągi obniżeń mis jeziornych i dolin rzecznych. Punktami węzłowymi są główne przecięcia ciągów kompozycyjno-funkcjonalnych. Ich bezpośrednie sąsiedztwo jest tylko w nielicznych miejscach należycie pokreślone. Elementami pojawiającymi się sporadycznie w tych miejscach są przydrożne obiekty kultu religijnego oraz infrastruktura drogowa.

Na terenie opracowania wydzielono 850 wnętrz krajobrazowych o łącznej powierzchni 228 km² (ryc. 2). Średnia powierzchnia wnętrza wynosi 26,9 ha. Największe ma powierzchnię 933 ha, najmniejsze 0,1 ha. Przeważają wnętrza niewielkie, o powierzchni kilku hektarów. Wnętrza krajobrazowe występujące na obszarze opracowania są w większości przypadków konkretne lub obiektywne. Są stosunkowo dobrze czytelne w krajobrazie. Ich struktura jest urozmaicona. Ścianami wnętrz są najczęściej ściany lasów, zadrzewień przydrożnych i śródpolnych. Charakterystyczna dla tego terenu jest niewielka liczba elementów wolnostojących w obrębie wnętrz. Kształt ich ścian jest w większości przypadków regularny. Sekwencje wnętrz, urozmaicone ukształtowanie terenu i rozproszone układy grup zieleni wysokiej wpływają znacząco na zasięg widoczności oraz wieloplanowość widoków. Częstym rodzajem są wnętrza długie. Występują one wzdłuż większości ciągów komunikacyjnych. Ściany ich formowane są przez nasadzenia alejowe, ściany lasów i zwartą zabudowę miejscowości, przez które przebiegają. Dużą rolę w ich czytaniu ma również porastająca pobocza roślinność ruderalna, która w przypadku przemieszczania się samochodem stanowi wystarczającą ścianę (obiektywną/subiektywną) zarysowującą kształt wnętrza. Ze względu jednak na skalę, w której było wykonywane niniejsze opracowanie, na mapie poglądowej zrezygnowano z rysowania tego typu wnętrz. Charakterystycznymi wnętrzami krajobrazowymi są wnętrza konkretne, związane z gospodarką leśną. Najliczniejsze są jednakże wnętrza krajobrazu rolniczego - obiektywne i konkretne. Większość z nich ma strukturę sprzężoną. Wnętrza tworzą charakterystyczne sekwencje. Krajobraz przydrożny w przypadku braku konkretnej lub obiektywnej ściany od strony drogi ma formę wnętrza kulisowego, otwartego widokowo. Zgodnie z teorią wnętrza krajobrazowego (urbanistycznego) przestrzeń składa się z następujących składowych: ścian, podłogi, sufitu, elementów wolnostojących (Bogdanowski 1998), które na badanym terenie stanowią:

- Ściany - są nimi w większości przypadków ściany lasów, zadrzewień śródpolnych, aleje przydrożne, szpalery przy ciekach i rowach melioracyjnych. W niektórych przypadkach ścianami są również zwarte układy ruralistyczne. Ścianami subiektywnymi są również ciągi komunikacyjne pozbawione regularnych nasadzeń liniowych. Rolę ścian pełni także roślinność nadjeziorna.

- Podłoga - w analizowanym układzie są to w większości przypadków przestrzenie nieutwardzone, głównie pola uprawne, łąki, pastwiska oraz nieużytki o niewielkim udziale zadrzewień i zakrzewień. Do tej kategorii zaliczono ponadto tafle jezior oraz nawierzchnie drogowe.

- Sufit - praktycznie w każdym przypadku jest sklepienie niebieskie (przykrycie pozorne). Jedynie w przypadku wnętrz długich (drogi gminne i powiatowe przecinające tereny leśne lub obsadzone nasadzeniami alejowymi) sufitem jest okap koron drzew.

- Elementy wolnostojące - biorąc pod uwagę skalę opracowania, jako elementy wolnostojące należy wskazać grupy zadrzewień, układy ruralistyczne, w tym zabudowę kolonijną, elementy infrastrukturalne itp. 


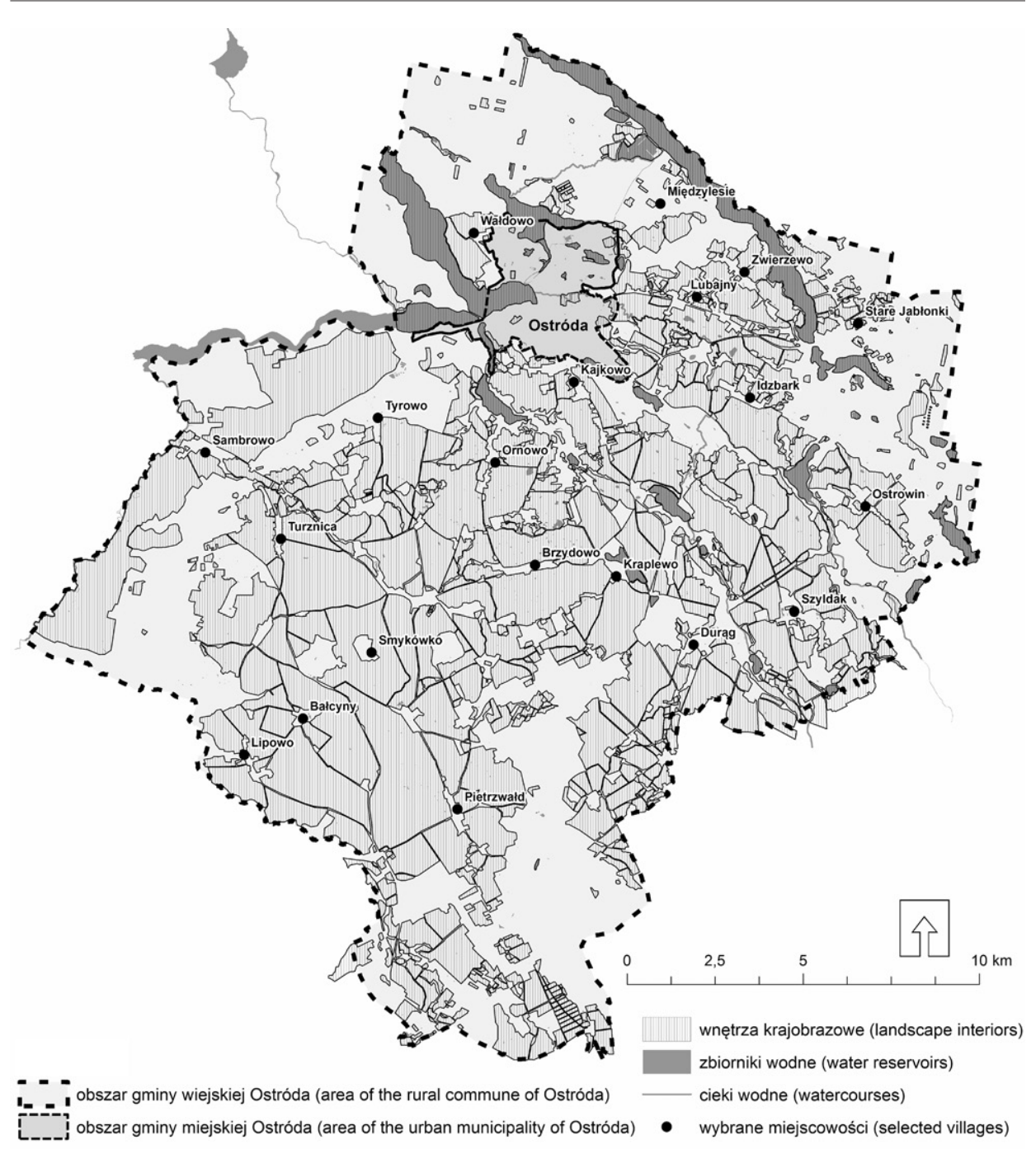

Ryc. 2. Wnętrza krajobrazowe występujące na terenie opracowania Landscape interiors occurring within the area of the study Źródło: opracowanie własne/Source: own study.

Elementami wyróżniającymi się na terenie opracowania są dominanty i subdominanty kulturowe oraz akcenty kulturowe i naturalne. Na terenie gminy wiejskiej Ostróda stwierdzono występowanie 23 dominant o charakterze kulturowym. Zaliczono do nich wyłącznie obiekty o ponadlokalnej sile oddziaływania. Są to:

- kościoły w Ornowie, Kajkowie, Durągu, Reszkach, Wałdowie i Glaznotach,

- dwory w Lubajnach, Grabinie i Klonowie,

- pałac w Szyldaku,

- zespoły folwarczne w Lipowie, Smykówku, Pancerzynie, Kraplewie, Ostrowinie i Bałcynach, 
- szkoła w Brzydowie,

- zakłady: utylizacji odpadów w Rudnie, usługowy w Górce, mięsne w Morlinach, silos w Samborowie,

- zespół stacji kolejowej w Starych Jabłonkach,

- wieża telewizyjna w Wysokiej Wsi.

W bezpośrednim sąsiedztwie badanego terenu nie występują ważne dominanty, widoczne z obszaru gminy. Wyjątek stanowią kościoły znajdujące się w Ostródzie dobrze widoczne z ciągu widokowego w okolicy Szafranek. Na analizowanym terenie stwierdzono występowanie sześciu subdominant kulturowych. Są nimi: kościół w Starych Jabłonkach, budynek gospodarczy z zespole stacji kolejowej w Samborowie, kościół w Szyldaku, Kraplewie i Glaznotach oraz zespół folwarczny w Szyldaku. Na terenie gminy stwierdzono występowanie stu akcentów kulturowych. Ważnymi akcentami są cmentarze ewangelickie. W niektórych przypadkach ich sylwety są dobrze wyeksponowane w krajobrazie. Przykładami są obiekty w Wirwajdach, Żurejnach i Idzbarku. Interesującymi akcentami są zabytkowe wiadukty kolejowe w Glaznotach, kaplice w Idzbarku, Zajączkach i Lipowie oraz zabytkowe parki. Kolejną grupą są przydrożne obiekty kultu religijnego. W krajobrazie gminy pojawiają się również sporadycznie akcenty naturalne. W terenie znajduje się 12 obiektów zaliczonych do tej kategorii. Są nimi m.in. głazy narzutowe (Glaznoty, Pancerzyn), imponujących rozmiarów drzewa dobrze wyeksponowane w krajobrazie (Bednarki, Czerwona Karczma), skupiny zadrzewień śródpolnych (Bałcyny, Zajączki, Buńki).

Podczas inwentaryzacji oznaczono główne elementy ekspozycji czynnej i biernej, mające kluczowe znaczenie w czytaniu krajobrazu. Zidentyfikowano ciągi i punkty widokowe, linie prowadzące wzrok oraz obiekty dobrze eksponowane z dużych odległości. Elementami ekspozycji czynnej na obszarze opracowania jest układ drogowy, pełniący rolę ciągów widokowych. Podczas badań krajobrazowych zinwentaryzowano widoki z wszystkich dróg krajowych, wojewódzkich, powiatowych i gminnych, znajdujących się w granicach opracowania, łącznie z drogami gruntowymi wykorzystywanymi w ramach turystyki rowerowej i pieszej. Dodatkowo zinwentaryzowano widoki z istniejących i nieczynnych linii kolejowych. W badaniach nie uwzględniono dróg wodnych, które również we fragmentach kwalifikują się do zaliczenia ich do ciągów widokowych. Zidentyfikowano 512 ciągów widokowych o łącznej długości 291,7 km. Do najcenniejszych zakwalifikowano:

- drogę powiatową 1235N (Wysoka Wieś - Pietrzwałd - Naprom - droga krajowa $\mathrm{nr}$ 15),

- drogę powiatową 1251N (Pancerzyn - Lichtajny),

- drogę powiatową 1233N (Wygoda - Glaznoty i Zajączki - Lipowo),

- drogę krajową nr 16 (dolina Drwęcy na wysokości Lubajn oraz odcinek: Samborowo - Tyrowo - Ostróda),

- drogę krajową nr 15 (Lipowo - Smykówko - Morliny),

- drogę krajową nr 7 (odcinki na południe od Ostródy w okolicach Grabina i Szyldaka).

Ważnymi elementami mającymi wpływ na ekspozycję są linie prowadzące wzrok. Są nimi głównie śródpolne i przydrożne szpalery drzew i krzewów. Linie te w dużej mierze są tożsame z granicami działek ewidencyjnych. W wyraźny sposób dzielą one wnętrza krajobrazowe oraz skutecznie odwracają wzrok wizualnych użytkowników przestrzeni w określonym kierunku. W terenie zidentyfikowano 162,6 km takich linii. 
Na terenie opracowania zidentyfikowano ponadto 10 punktów widokowych. Najbardziej dostępnymi z nich są: punkt widokowy na jezioro Szeląg Wielki z parkingu przy drodze krajowej nr 16, punkt widokowy na szczycie Góry Dylewskiej przy ścieżce dydaktycznej oraz punkt widokowy na jezioro Szeląg Wielki na terenie kąpieliska w Kątnie. W przypadku kolejnych punktów widokowych ich dostępność jest częściowo ograniczona, co związane jest głównie z własnością terenu. Punktami wartymi odnotowania są: widok na Ostródę z Góry Napoleona w Kajkowie, widok z wieży kościoła w Kajkowie, widok z wieży przeciwpożarowej na szczycie Góry Dylewskiej, widok na jezioro Pauzeńskie z pomostu w salezjańskim ośrodku wypoczynkowym, widok na malowniczy krajobraz rolniczy z byłej linii kolejowej w Lichtajnach, widok na jezioro Szeląg Wielki z ośrodka wypoczynkowego w miejscowości Szeląg (przy granicy gminy) czy widok z wieżyczki zabytkowego dworu w Klonowie. Obiekty dobrze eksponowane z dużych odległości podzielono na trzy kategorie. Za obiekty o charakterze negatywnym uznano: silosy w Samborowie, zakłady mięsne w Morlinach, zakład produkcyjny w Górce, kościół w Wałdowie oraz zakład utylizacji odpadów w Rudnie. Obiektami neutralnymi są kościół w Reszkach i wieża przeciwpożarowa w Wysokiej Wsi. Harmonijnie wpisane w krajobraz są natomiast: wiadukt w Glaznotach oraz kościoły w Glaznotach, Durągu, Ornowie i Kajkowie. Interesującymi elementami, wpływającymi na jakość krajobrazu, są liczne widoki osiowe, czytelne na prostych fragmentach dróg podkreślonych nasadzeniami alejowymi lub o ścianach zadrzewionych/zalesionych, otwarcia widokowe zawierające cenne ujęcia krajobrazu kulturowego, zamknięcia i otwarcia na zakończeniach osi widokowych i inne.

\section{Analiza i waloryzacja krajobrazów wybranych miejscowości}

Do szczegółowej analizy krajobrazu wybrano 20 miejscowości znajdujących się na terenie gminy wiejskiej Ostróda liczących powyżej 300 mieszkańców. Są nimi: Samborowo, Tyrowo, Kajkowo, Szyldak, Stare Jabłonki, Lubajny, Idzbark, Brzydowo, Smykówko, Pietrzwałd, Lipowo, Zwierzewo, Wałdowo, Międzylesie, Turznica, Ostrowin, Durąg, Ornowo, Kraplewo i Bałcyny. Dla każdej z nich opracowano dwie karty krajobrazu. Pierwsza z kart (ryc. 3) zawiera opis miejscowości oraz mapę z lokalizacją wsi na tle gminy. Część kartograficzna składa się z czterech map: ogólnej topograficznej, ortofotomapy oraz dwóch topograficznych map pochodzących z XX wieku. Na karcie tej zaprezentowano ponadto składowe krajobrazu: ukształtowanie terenu (NMT), wody powierzchniowe, układ drogowy, zabudowę oraz wybrane układy zieleni (lasy, zagajniki, zakrzewienia). Ważnym elementem karty jest część związana z ochroną i planowaniem krajobrazu, w której przedstawione są obiekty znajdujące się w ewidencji i rejestrze zabytków, powierzchniowe formy ochrony przyrody oraz obowiązujące miejscowe plany zagospodarowania przestrzennego i decyzje o warunkach zabudowy wydane na terenie opracowania na przestrzeni lat 2007-2011. Druga karta (ryc. 4) zawiera uproszczoną analizę krajobrazową (część kartograficzna i tekstowa), dokumentację fotograficzną terenu oraz mapę z lokalizacją miejscowości na terenie gminy.

Dla 20 miejscowości objętych analizą wykonano ponadto uproszczoną waloryzację w postaci tabelarycznej (tab. 1). Ocenie poddano następujące czynniki:

1. ukształtowanie terenu - stopień zróżnicowana rzeźby terenu i jej pochodzenie $(4,2,0$ pkt), 
2. wody powierzchniowe - zróżnicowanie i zagęszczenie różnych typów wód powierzchniowych (4, 2, 0 pkt),

3. fauna i flora - zróżnicowanie i stopień antropogenicznych przekształceń, typy formacji roślinnych i układów komponowanej zieleni (4, 2, 0 pkt),

4. architektura - walory estetyczne i historyczne zabudowy dominującej we wsi, obecność form obcych (4, 2, 0 pkt),

5. układ przestrzenny - ocena stanu istniejącego rozplanowania wsi w stosunku do zabudowy pochodzącej z lat 30. XX w. (4, 2, 0 pkt),

6. charakterystyczne obiekty i układy przestrzenne - zagęszczenie obiektów takich jak cmentarze, założenia folwarczne, pałacowe, dworskie i parkowe, przydrożne obiekty kultu religijnego (4, 2, 0 pkt),

7. infrastruktura techniczna - zagęszczenie nadziemnych elementów infrastruktury technicznej wpływających negatywnie na odbiór wizualny miejscowości $(-4,-2$, 0 pkt),

8. zagospodarowanie turystyczne - zagęszczenie i harmonia systemu infrastruktury turystycznej (4, 2, 0 pkt),

9. ochrona przyrody - stopień pokrycia miejscowości powierzchniowymi formami ochrony przyrody (4, 2, 0 pkt),

10. ochrona zabytków - zagęszczenie obiektów widniejących rejestrze i ewidencji zabytków (4, 2, 0 pkt),

11. ekspozycja - czytelność sylwety miejscowości w krajobrazie, rola dominanty oraz zagospodarowanie przedpola widokowego (2,0 pkt),

12. elementy wyróżniające się - występowanie dominant, subdominant i akcentów kulturowych i naturalnych, ich siła i charakter oddziaływania (4, 2, 0 pkt),

13. harmonia krajobrazu - sposób wpisania miejscowości w krajobraz oraz występowanie obiektów obcych krajobrazowo (4, 0 pkt).

Wybór kategorii oceny oraz punktacja poszczególnych składowych została zaproponowana po przeprowadzeniu inwentaryzacji terenowej. Została ona dostosowana do uwarunkowań lokalnych. Minimalną możliwą do uzyskania liczbą punktów było-4, maksymalną 46. Miejscowościami, które uzyskały najniższą liczbę punktów, w przedziale 0-10, są: Smykówko (4), Wałdowo (6) i Międzylesie (8). Najwyżej (31-40) oceniono miejscowości: Pietrzwałd (32), Ostrowin (32), Kraplewo (36) i Durąg (38). Wyniki waloryzacji przekładają się na rzeczywiste walory krajobrazowe miejscowości. Nie pokrywają się jednak z powierzchniowymi formami ochrony krajobrazu, które wyznaczono na terenie gminy. Wysoko sklasyfikowane w waloryzacji miejscowości takie jak: Ornowo, Brzydowo czy Turznica, leżą na obszarach, których nie objęto ochroną. 
Tabela 1. Waloryzacja wybranych miejscowości znajdujących się na terenie gminy wiejskiej Ostróda

\begin{tabular}{|c|c|c|c|c|c|c|c|c|c|c|c|c|c|c|c|}
\hline \multirow[b]{2}{*}{ Lp. } & \multirow[b]{2}{*}{$\begin{array}{c}\text { Nazwa } \\
\text { miejscowości }\end{array}$} & \multicolumn{13}{|c|}{ Kryteria oceny } & \\
\hline & & 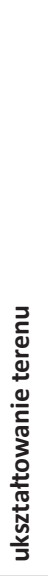 & 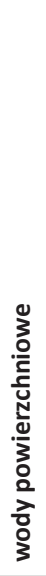 & 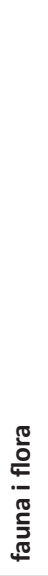 & 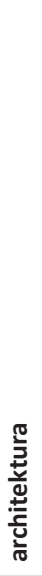 & 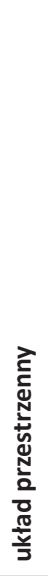 & 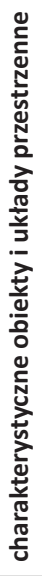 & 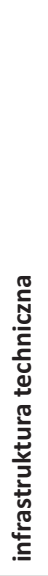 & 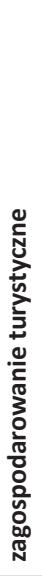 & 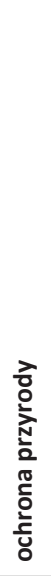 & 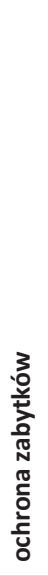 & $\begin{array}{l}\frac{\pi}{3} \\
\frac{0}{0} \\
\frac{0}{2} \\
\frac{0}{0}\end{array}$ & 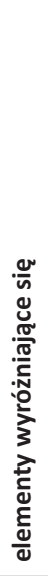 & 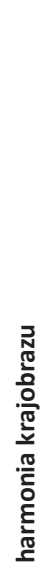 & $\stackrel{\overbrace{}}{\xi}$ \\
\hline 1. & Samborowo & 0 & 4 & 4 & 2 & 0 & 2 & -4 & 2 & 2 & 4 & 0 & 2 & 0 & 18 \\
\hline 2. & Tyrowo & 4 & 2 & 0 & 2 & 2 & 4 & -2 & 2 & 0 & 2 & 2 & 2 & 0 & 20 \\
\hline 3. & Kajkowo & 4 & 4 & 0 & 2 & 0 & 0 & -2 & 2 & 0 & 2 & 0 & 4 & 0 & 16 \\
\hline 4. & Szyldak & 0 & 2 & 2 & 4 & 2 & 4 & -2 & 2 & 2 & 4 & 0 & 4 & 0 & 24 \\
\hline 5. & Stare Jabłonki & 4 & 4 & 4 & 0 & 0 & 2 & -4 & 4 & 4 & 4 & 0 & 2 & 0 & 24 \\
\hline 6. & Lubajny & 2 & 0 & 4 & 0 & 0 & 2 & -2 & 2 & 2 & 2 & 0 & 2 & 0 & 14 \\
\hline 7. & Idzbark & 0 & 0 & 0 & 2 & 4 & 2 & -2 & 2 & 2 & 2 & 2 & 2 & 4 & 20 \\
\hline 8. & Brzydowo & 0 & 2 & 2 & 4 & 4 & 2 & 0 & 2 & 2 & 2 & 2 & 2 & 4 & 28 \\
\hline 9. & Smykówko & 0 & 0 & 0 & 0 & 0 & 2 & -2 & 0 & 2 & 2 & 0 & 0 & 0 & 4 \\
\hline 10. & Pietrzwałd & 2 & 2 & 2 & 4 & 4 & 2 & 0 & 2 & 4 & 2 & 2 & 2 & 4 & 32 \\
\hline 11. & Lipowo & 2 & 2 & 2 & 2 & 2 & 4 & -2 & 0 & 2 & 4 & 0 & 2 & 0 & 20 \\
\hline 12. & Zwierzewo & 2 & 2 & 2 & 2 & 4 & 2 & 0 & 2 & 2 & 2 & 2 & 0 & 4 & 26 \\
\hline 13. & Wałdowo & 0 & 2 & 0 & 0 & 0 & 2 & -2 & 2 & 0 & 0 & 0 & 2 & 0 & 6 \\
\hline 14. & Międzylesie & 0 & 0 & 4 & 0 & 0 & 0 & 0 & 2 & 2 & 0 & 0 & 0 & 0 & 8 \\
\hline 15. & Turznica & 2 & 2 & 2 & 4 & 4 & 4 & -2 & 2 & 0 & 2 & 2 & 2 & 4 & 28 \\
\hline 16. & Ostrowin & 2 & 2 & 4 & 2 & 4 & 4 & 0 & 0 & 2 & 4 & 2 & 2 & 4 & 32 \\
\hline 17. & Durąg & 4 & 2 & 4 & 4 & 2 & 4 & 0 & 2 & 2 & 4 & 2 & 4 & 4 & 38 \\
\hline 18. & Ornowo & 4 & 2 & 0 & 2 & 4 & 2 & 0 & 2 & 0 & 2 & 2 & 4 & 4 & 28 \\
\hline 19. & Kraplewo & 2 & 4 & 2 & 4 & 2 & 4 & 0 & 4 & 2 & 4 & 2 & 2 & 4 & 36 \\
\hline 20. & Bałcyny & 0 & 2 & 2 & 2 & 2 & 4 & -2 & 0 & 4 & 4 & 0 & 2 & 0 & 20 \\
\hline
\end{tabular}

Źródło: opracowanie własne. 


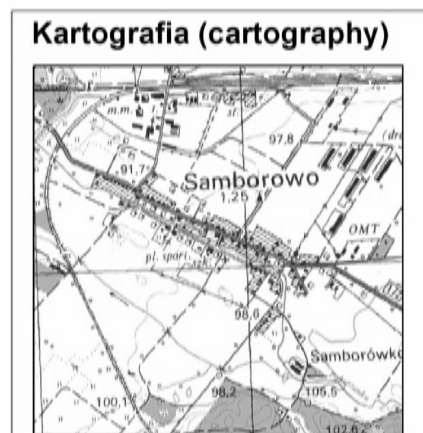

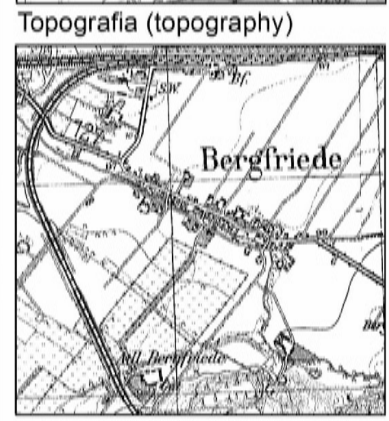

Mapa historycznáa (lata 30-te XX w) (historic map - 30's of the 20th century)
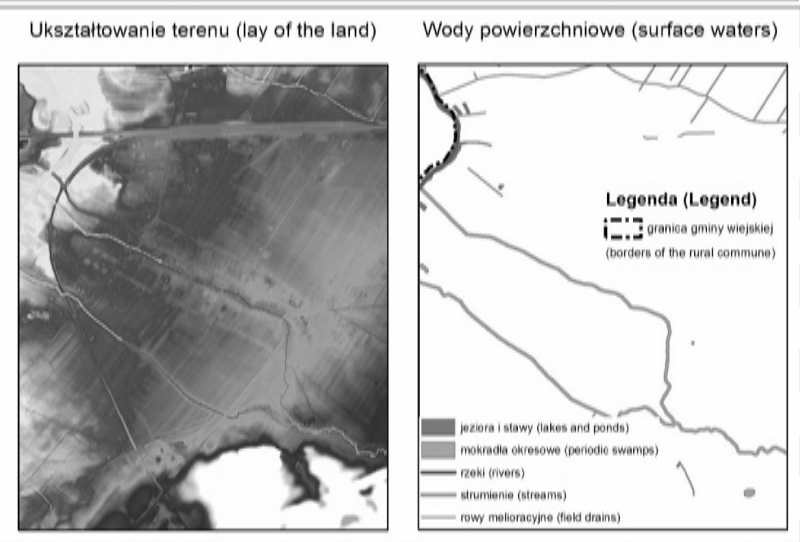

Ryc. 3. Karta krajobrazu miejscowości Samborowo (1/2) Landscape chart for the locality of Samborowo (1/2) Źródło: opracowanie własne/Source: own study. 
Opis miejscowości

\section{SAMBOROWO}

Samborowo jest największą miejscowością znajdującą się na terenie gminy wiejskiej Ostróda.

Miejscowość leży przy wschodniej granicy gminy przy drodze krajowej nr 16.

Wieś usytuowana jest w dolinie rzeki Drwęcy, a przez środek miejscowości

przepływa Podburska Struga. Pierwotny układ przestrzenny wsi to łańcuchówka, współcześnie został on znacząco przekształcony. Miejscowość w 2012 r.

zamieszkiwało 1446 osób.

Characteristic of the village

Samborowo is the biggest village in the Ostróda rural commune. The village is situated in the eastern part of the commune in the river Drwęca valley, close to the trunk road no. 16.

Through the middle of Samborowo passes Podburska Struga. Original spatial

layout of the village was waldhufendorf. During last years it was significantly changed. In 2012 Samborowo

was inhabited by 1446 persons.

Lokalizacja na tle gminy (location on the background of the commune)

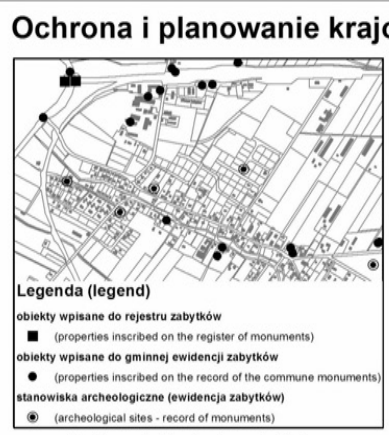

Ewidencja i rejestr zabytków (record and register of monuments)

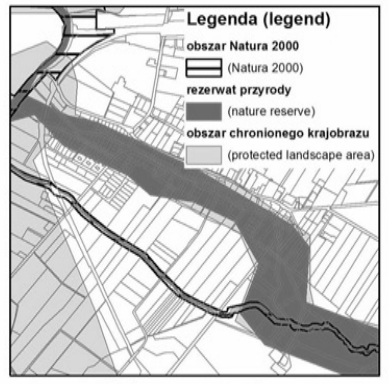

Ochrona przyrody (environmental protection)

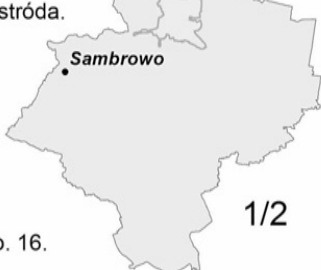

$1 / 2$
Układ drogowy (road layout)

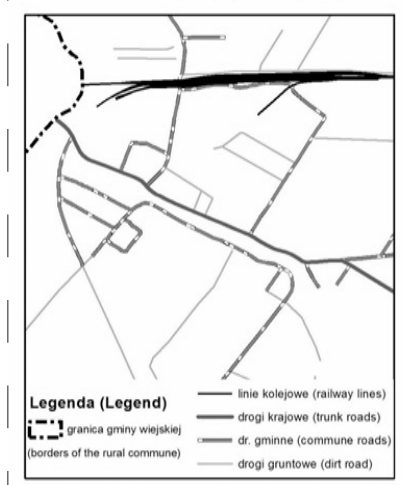

Zabudowa (buildings) Wybrane układy zieleni (selected green systems)
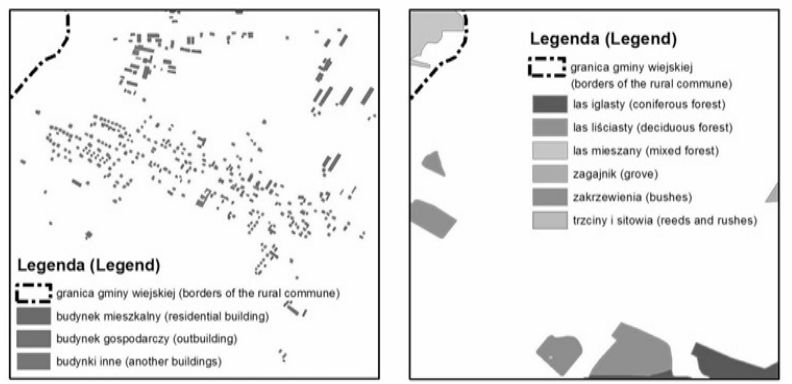

Składowe krajobrazu (landscape components) 
Dokumentacja fotograficzna (photographic documentation)

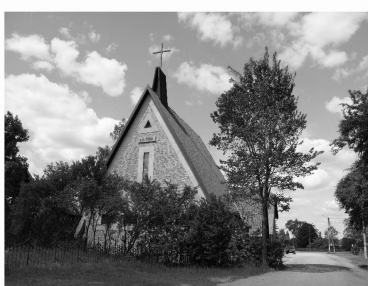

Fot. 1. Kościół - akcent kulturowy Pic. 1. The church - cultural accent

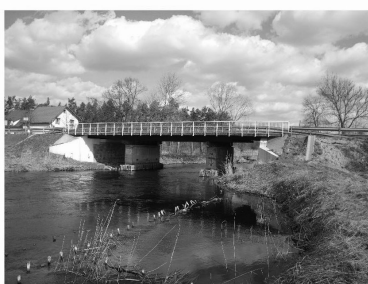

Fot. 3. Most drogowy nad Drwęcą Pic. 3. The road bridge over Drwęca

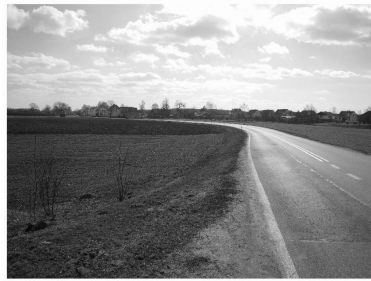

Fot. 5. Zachodnia panorama wsi Pic. 5. West skyline of Samborowo

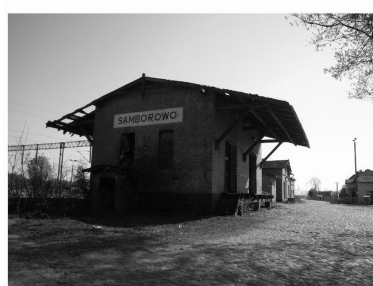

Fot. 7. Zabytkowy magazyn Pic. 7. Historic warehouse

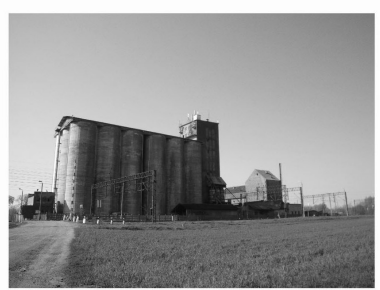

Fot. 2. Elewator zbożowy - dominanta Pic. 2. The grain elevator - dominant

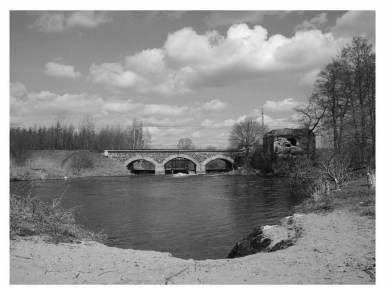

Fot. 4. Zabytkowy most kolejowy Pic. 4. Historic rail bridge

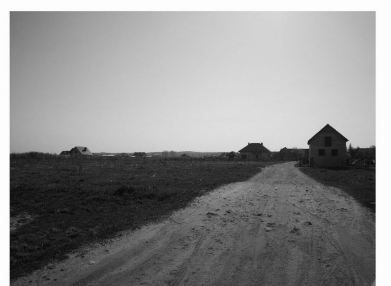

Fot. 6. Współczesna zabudowa Pic. 6. Contemporary development

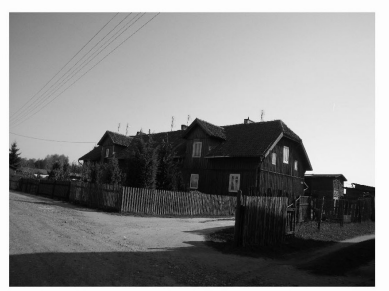

Fot. 8. Zabytkowy budynek mieszkalny Pic. 8. Historic residential building

Ryc. 4. Karta krajobrazu miejscowości Samborowo (2/2) Landscape chart for the locality of Samborowo (2/2) Źródło: opracowanie własne/Source: own study. 


\section{Analiza krajobrazowa}

1. SAMBOROWO

Dominantą krajobrazową miejscowości jest elewator zbożowy dobrze eksponowany z dużych odległości. Rolę subdominanty pełni położony nieopodal zabytkowy magazyn. Głównymi akcentami kulturowymi są: zespół dworca kolejowego, dwa cmentarze, kościół, szkoła

i wieże obronne mostu kolejowego. Interesujące ciągi widokowe rozpościerają się $z$ linii kolejowej oraz dróg wiejskich na obrzeżach miejscowości. Zwarta zabudowa najstarszej części wsi tworzy ściany konkretnych i obiektywnych wnętrz krajobrazowych.

\section{Landscape analysis}

Landscape dominant of the village is the grain elevator, which is well exposed from a long distance. Historic warehouse situated close to the elevator is the subdominant of the village. The main cultural accents are: the railway station complex, the church, the school, the defensive towers on the rail bridge and two cemeteries. Interesting panoramic views are to be seen from the railway lines and from the local roads on the outskirts of the village. Concentrated settlements of the oldest part of the village creates the walls of particular and objective landscape interiors.

\section{Lokalizacja na tle gminy (location on the background of the commune)}

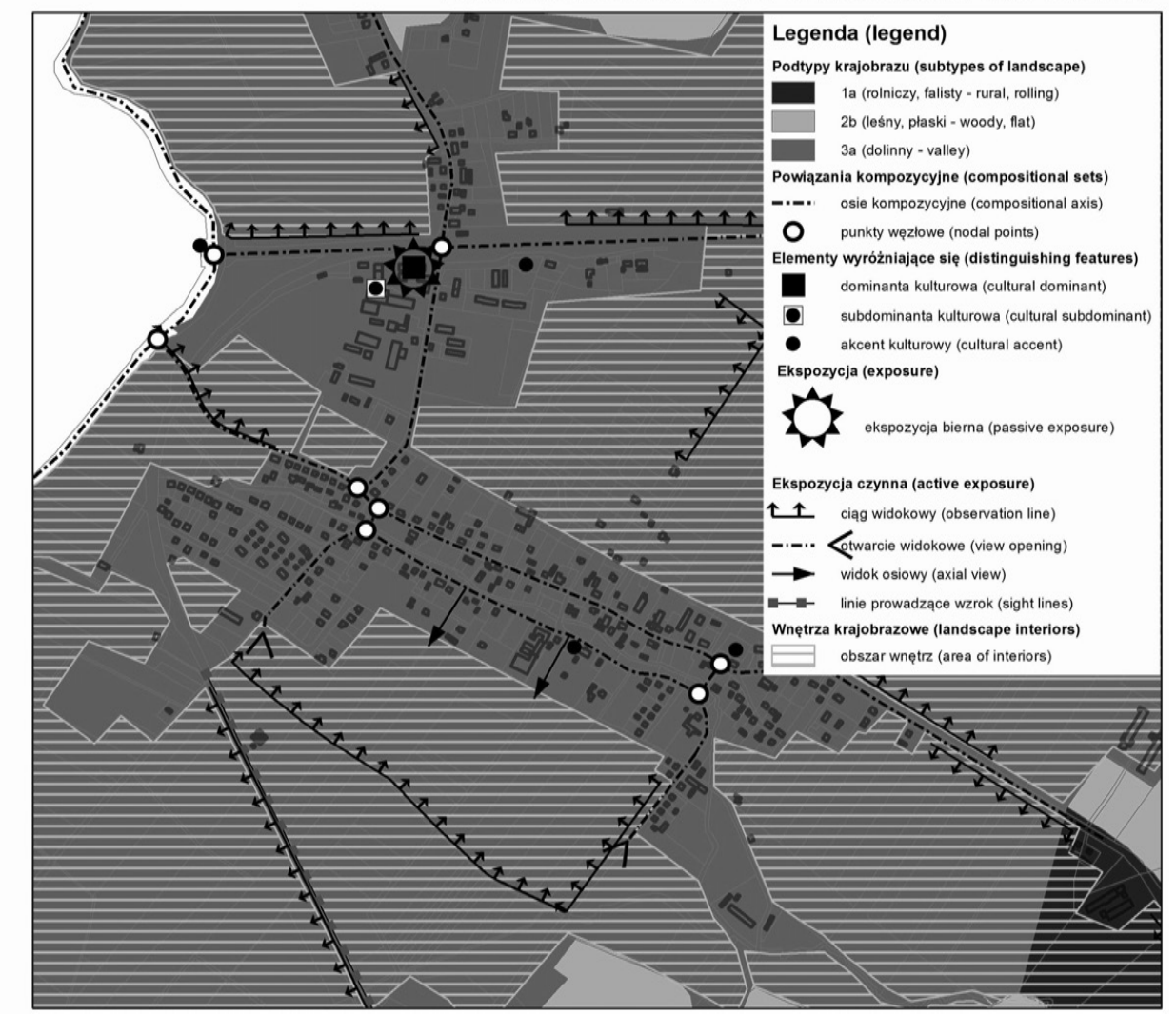




\section{Podsumowanie}

Teren opracowania charakteryzuje się wysokimi walorami krajobrazowymi, podlegającymi współcześnie wyraźnym przekształceniom. W celu zachowania tych wartości należy wykonać szereg działań o charakterze ochronnym, ale także właściwie planować krajobraz. Należy dążyć do zachowania istniejącego układu alei przydrożnych, będących ważnym elementem podkreślającym rolę ciągów kompozycyjno-funkcjonalnych oraz podkreślać projektowane ciągi nowymi układami alejowymi. W miejscowościach posiadających dominanty krajobrazowe należy uporządkować ich przedpola widokowe oraz unikać lokalizowania nowych obiektów mogących przejąć ich rolę. Należy dążyć do podkreślenia roli akcentów kulturowych (głównie przydrożnych obiektów kultu religijnego) przez właściwe zagospodarowanie terenu do nich przylegającego. W uzasadnionych przypadkach należy rozważyć możliwość podkreślenia punktów węzłowych akcentami kulturowymi lub naturalnymi. Należy utrzymać istniejący układ wnętrz krajobrazowych, których ściany tworzą w większości przypadków linearne układy zadrzewień - alei przydrożnych i śródpolnej roślinności porastającej miedze. Na terenie badanej gminy należy stworzyć sieć ogólnodostępnych, dobrze oznakowanych punktów widokowych - wieże i platformy widokowe (Góra Napoleona w Kajkowie, Góra Dylewska w Wysokiej Wsi, Góra Czubatka w Wygodzie, okolice Tyrowa i Lubajn z widokiem na Dolinę Drwęcy, Kątno z widokiem na Szeląg Wielki, Stare Jabłonki z widokiem na Szeląg Mały, Idzbark z widokiem na jezioro Ostrowin i dolinę Drwęcy). W miejscowych planach zagospodarowania przestrzennego należy wprowadzić bezwzględny zakaz zabudowywania przedpól widokowych obiektów zabytkowych, pełniących rolę lokalnych dominant krajobrazowych (głównie kościoły, pałace, dwory, wiadukty). Należy dążyć do ekspozycji interesujących widoków z dróg znajdujących się na terenie opracowania poprzez coroczne usuwanie roślinności przesłaniającej cenne widoki (nie stanowiącej wartościowego siedliska). Problemem są zarówno gatunki inwazyjnych roślin zielnych, jak i siewki niezwykle żywotnych gatunków drzew, jak np. klon zwyczajny (Acer platanoides). Należy zwrócić szczególną uwagę na ekspozycję interesujących widoków z projektowanych dróg i nie dopuścić do tworzenia korytarzy infrastrukturalnych w oderwaniu od lokalnego krajobrazu. Należy ponadto świadome kształtować nasypy przydrożne oraz lokalizować ekrany akustyczne wyłącznie w uzasadnionych przypadkach. Ich forma powinna być atrakcyjna wizualnie (preferowany materiał: drewno na podmurówce z czerwonej cegły, roślinność pnąca - winobluszcz pięciolistkowy Murorum (Parthenocissus quinquefolia). Bardzo ważne znaczenie w ekspozycji interesujących widoków mogą mieć linie prowadzące wzrok - projektowane w postaci nasadzeń śródpolnych. Należy także dążyć do stworzenia sekwencji okien widokowych w ciągu dróg krajowych (Antolak 2013).

Studia krajobrazowe, jako element nieobligatoryjny systemu planowania przestrzennego, są wykonywane niezwykle rzadko i mało kiedy sporządza się je dla terenów całych gmin. Mogą one jednakże stanowić podstawę do ochrony i właściwego kształtowania struktury krajobrazu. Zaprezentowane w pracy studium przypadku obrazuje zakres opracowania, który po dostosowaniu do lokalnej specyfiki terenu może być wykorzystywany jako materiał wejściowy przy sporządzaniu studiów uwarunkowań i kierunków zagospodarowania przestrzennego gmin. 


\section{Literatura}

Antolak M. 2013,. Kształtowanie i ochrona krajobrazów gmin na przykładzie gminy wiejskiej i miejskiej Ostróda, Wydział Architektury Politechniki Krakowskiej im. T. Kościuszki, Kraków (rozprawa doktorska).

Bajerowski T., 1991, Ocena, ochrona i kształtowanie krajobrazu wiejskiego, jako składnik programowania prac urzadzeniowo-rolnych, Uniwersytet Warmińsko-Mazurski, Olsztyn (rozprawa doktorska).

Bajerowski T., 1996, Metodyka wyboru optymalnego użytkowania ziemi na obszarach wiejskich, Wydawnictwo Akademii Rolniczo-Technicznej, Olsztyn.

Bogdanowski J., 1976, Kompozycja i planowanie w architekturze krajobrazu, Ossolineum, Wrocław-Kraków.

Bogdanowski J., 1998, Konserwacja i ochrona krajobrazu kulturowego (ewolucja metody), Teki krakowskie, VI. Regionalny Ośrodek Studiów i Ochrony Środowiska Kulturowego w Krakowie, Kraków, s. 37-38.

Bogdanowski J., Łuczyńska-Bruzda M., Novák Z., 1981, Architektura krajobrazu, PWN, Warszawa-Kraków.

Böhm A., 1981, O budowie i synergii wnętrz urbanistycznych, Wydawnictwo Politechniki Krakowskiej, Kraków.

Böhm A., 1998, Wnętrze w kompozycji krajobrazu, Wydawnictwo Politechniki Krakowskiej, Kraków.

Böhm A., 2006, Planowanie przestrzenne dla architektów krajobrazu - o czynniku kompozycji, Wydawnictwo Politechniki Krakowskiej, Kraków.

Ciołek G., 1964, Zarys ochrony i kształtowania krajobrazu, Arkady, Warszawa.

Patoczka P., 2000, „Ściany” i „bramy” w krajobrazie, Wydawnictwo Politechniki Krakowskiej, Kraków.

Pawłowska K. (red.), 2001, Architektura krajobrazu a planowanie przestrzenne, Wydawnictwo Politechniki Krakowskiej, Kraków.

\section{Summary}

The article presents the original methodological tools for analysing and valuing the landscape of the rural community designed for the purposes of spatial planning. The research covered the rural commune of Ostróda, with an area of $401 \mathrm{~km}^{2}$. Under the analysis, the area of the study was classified into landscape units (landscape types and subtypes). The following features were analysed in the studied area: composition links, landscape interiors, distinguishing elements and exposition. 20 localities with population over 300 people were selected for detailed landscape analyses. Two landscape charts were developed for each locality. For localities covered by the analysis, a simplified valuation in a table form was performed. The evaluation included the following factors: landform features, surface waters, fauna and flora, architecture, spatial arrangement, characteristic buildings and spatial arrangements, technical infrastructure, tourism infrastructure, environmental protection, protection of historical monuments, exposure, distinguishing elements and landscape harmony. The results of the landscape valuation revealed relatively high discrepancies between landscape protection areas and areas of the highest landscape values. 
http://rcin.org.pl 